مقاله يخوهشى

مجله دانشگاه علوم يزشكى رفسنجان

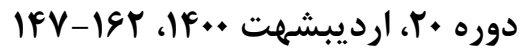

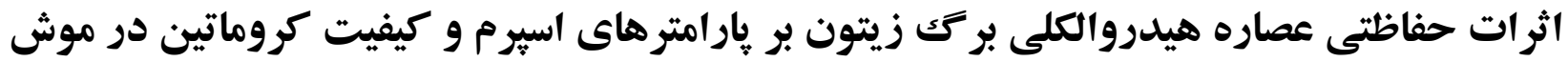

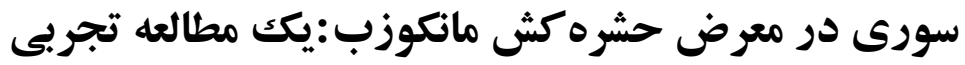

\section{مريم اشكنانى '، حكيمه اكبرى}

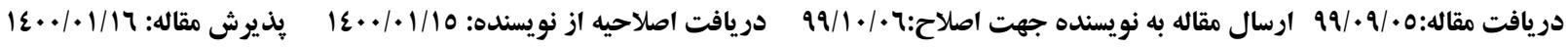

زمينه و هدف: استفاده بىرويه از مانكوزب (Mancozeb; MZB)، منجر به صدمات دستگاه تناسلى مى گردد. هدف مطالعه حاضر تعيين تأثير دوزهاى مختلف عصاره هيدروالكلى برى زيتون (Olive leaf extract; OLE) بر آسيب توليد مثلى در موشهاى نر در معرض مانكوزب بوده است.

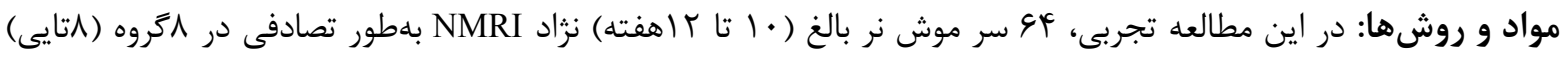

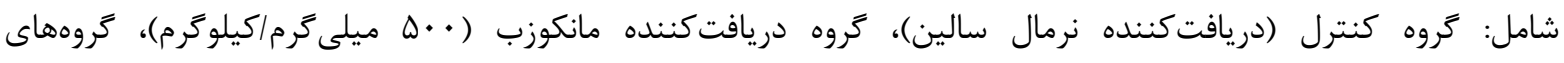

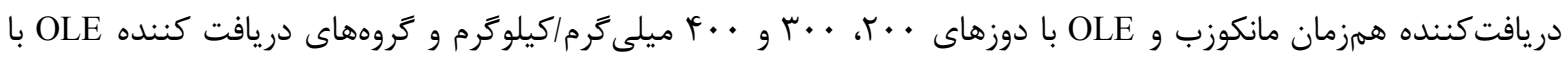

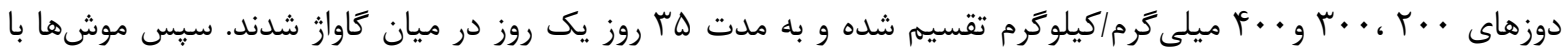
قطع نخاع گردنى كشته شده، نمونه خون قلب جهت اندازمخيرى سطح تستوسترون سرم جدا شد و إيديديم بلمنظور بررسى

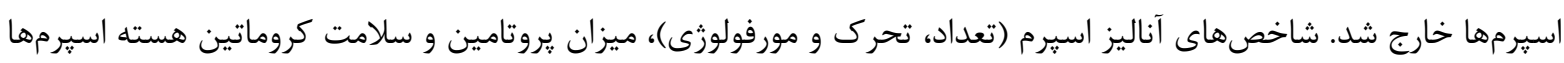

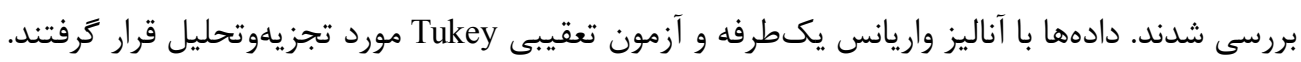

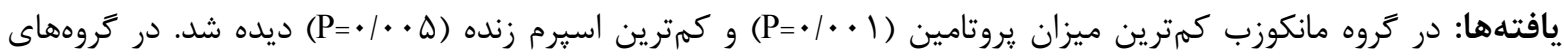

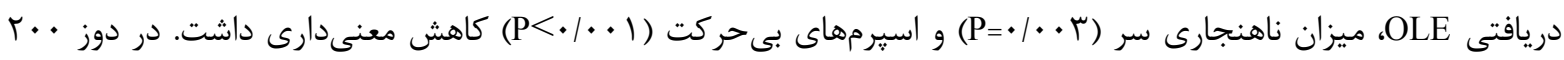
ميلى

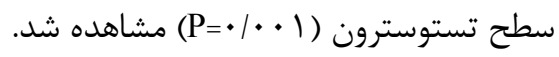

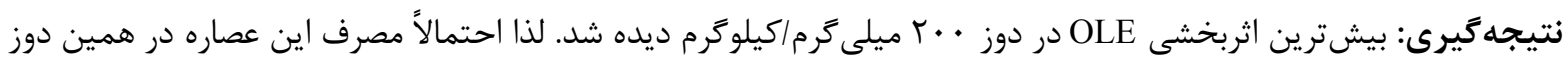
مىتواند بهعنوان يك تركيب حمايتى در رزيم غذايى افراد يرخطر در معرض مانكوزب لحاظ شود. وازههاى كليدى: مانكوزب، اسيرم، عصاره برى زيتون، موش سورى، نابارورى

\footnotetext{
1- دانشجوى كارشناسى ارشد بيوشيمى، گروه بيوشيمى، دانشكاه آزاد اسلامى واحد شيراز، شيراز، ايران

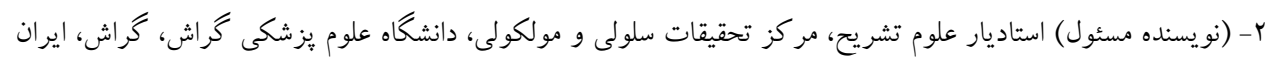

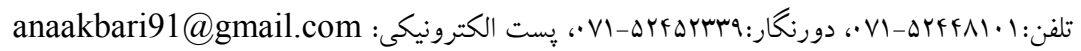


برگ زيتون (Olea europaea .L) بهنوان يك ماده خام و

مقدمه

ارزان سرشار از تركيبات فنولى بويزه اولئورويين مىباشد. مطالعات متعدد آزمايشگاهى (oleuropein)

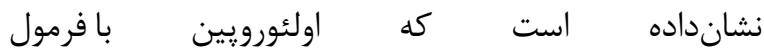
شيميايى C25H32O13 يكى از مهمترين تركيبات فنلى موجود در برگ و ميوه زيتون مىباشد كه تلخى برگ و ميوه زيتون به دليل وجود اولئورويين در آن است. اولئورويين، يك استر هتروسيديك از اسيد النوليك و r.أ- دى هيدروكسى فنيل اتانول مىباشد كه فعاليت ضد التهابى و آنتىاكسيدانى دارد [^]. با توجه به اثرات ضد التهابى، ضد ميكروبى و آنتىاكسيدانى اولئورويين موجود در برى زيتون [9]، هدف از اين مطالعه تعيين اثر حفاظتى عصاره برى زيتون بر اختلالات ناشى از مانكوزب در يارامترهاى اسيرم موش سورى مىباشد. با حصول نتايج مثبت مىتوان از عصاره برى زيتون در رزيم هاى غذايى افرادى كه به طور مستقيم و مداوم با مانكوزب سروكار دارند استفاده نمود.

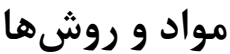

اين مطالعه تجربى، بر روى \&\& سر موشسورى نر بالغ نزاد NMRI در محدوده سنى זI-•| هفته در حيوانخانه مركز تحقيقات دانشكده علوم يزشكى شيراز در سال 99٪1 انجام شد. اين موشها در قفسهاى تميز خانه حيوانات با درجه حرارت F ت تا TF درجه سانتى Fراد و دوره تاريكىروشنايى II ساعته و رطوبت له درصد نَهدارى شدند. همرجنين حيوانات به صورت آزادانه به آب و غذا دسترسى داشتند. تمام مراحل آزمايش مطابق دستورالعمل مراقبت و استفاده از حيوانات آزمايشگاهى دانشگاه بود. در طول
نابارورى يكى از مشكلات جوامع امروزى، خصوصاً در بين زوجهاى جوان مىباشد. درصد بالايى از زوجها به اختلالات و مشكلات نابارورى مبتلا مىباشند. امروزه • ل-- r درصد علت ناباروى، مربوط به جنسمذكر باشد [؟-1]. برخى اختلالات نابارورى در مردان در ارتباط با پارامترهاى مايعمنى و سلولهاى اسيرم مىباشد. اختلال در يارامترهايى مانند كاهش تعداد اسيرم، عدم توليد و بلوغ اسيرمهاى طبيعى، اختلال در حركت اسيرمها و ساختار كروماتين و هسته مىتواند منجر به نابارورى در مردان گردد [1]. اسيرماتوزنز فرآيندى بسيار يُجِيده است كه عوامل متعددى مىتواند بر آن اثر كرده و منجر به نابارورى و يا كاهش بارورى در فرد شود [r-r]. شواهد نشان مىدهد كه تماس با حشرهكشها مىتواند زنهاى والدين را تحت تأثير قرار داده و بر روى فرزندان و نهايتأ نسلهاى بعدى تأثير بحذارد [\&]. بيش از • ^ درصد از حشرهشهاى قابل دسترس براى مصارف كشاورزى و خانكى، داراى تركيبات كربامات و يا اركانوفسفاتها هستند كه مىتوانند باعث ايجاد اختلال عملكرد اندوكرينى در موشهاى صحرايى نر شوند [ه]]. دستخاه توليد مثل هر دو جنس، به دليل تخريب مكانيزمهاى فيدبكى ناشى از اثرات منفى اين حشرهكشها از جمله مانكوزب (Mancozeb) با فرمول شيمايى C C و نام تجارى مانكوزب ديتانام (Alkylenebis از خروه شيميايى (Dithane M) - dithiocarbamate) كونادال نسبت به اين عوامل آسيب ريذير مىباشند [ع-V]. 
پايان مرداد ماه از سيفآباد كازرون تهيه شده و بعد از تأييد نام علمى گياه Olea L)europaea) در گروه فارماكوكنوزى دانشكده داروسازى شيراز، يك نمونه هرباريومى از خياه، در هرباريوم دانشكده قرار گرفت (KF 1434). به طور خلاصه جهت تهيه عصاره، مقدار · F Fرم برى زيتون بعد از خشك شدن، آسياب (مدل A11 Basic Analytical mill كميانى IKA آلمان) و عبور دادن از الك با مش . •r با روش ماسراسيون با اتانول •^ درصد عصارگگيرى شد. مدت عصارهگيرى VT ساعت مىباشد كه هر TY ساعت يك مرتبه بعد از جدا كردن عصاره، حلال تازه به نمونه اضافه شد. بعد از جمعآورى كل عصاره به وسيله دستكاه تقطير در خلاء (مدل RV10 Control از كميانى IKA آلمان) تغليظ و در دماى كمتر از • د درجه سانتى Fراد به مدت TF ساعت خشك گرديد. عصاره خشك و توزين شده تا زمان انجام

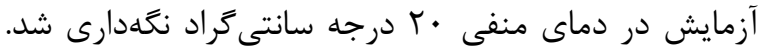
با توجه به اينكه عمده تركيبات برى زيتون از دسته فلاونوئيدها و اسيدهاى فنوليك مىباشند، لذا به منظور Thin layer استانداردسازى عصاره گَياهى با انجام كروماتوگرافى و تعيين فلاونوئيد غالب گياه، در .. أرم از اين عصاره برى زيتون، محتواى كل فلاونوئيد سع/ا گرم با استفاده از منحنى كاليبراسيون روتين و محتواى فنلى كل

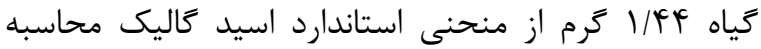
Oد. به اين طريق عصاره بركزيتون گونه Olea europaea تهيه شد [11]. . يس از ها روز تيمار طبق تقسيمبندى كَوهها، موشهاى هر گروه به روش نخاعى كشته شدند. يس از جراحى و بازكردن اسكروتوم، ناحيه وازدفران جٍ جدا
آزمايشات از حيوانآزارى خوددارى گرديد. اين مطالعه حاصل باياننامه كارشناسى ارشد دانشجوى دانشعاه آزاد

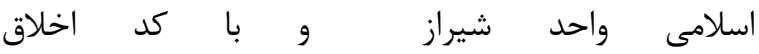
IR.IAU.SHIRAZ.REC.1399.027 مىباشد.

مانكوزب مورد استفاده (CAS: 8018-01-7) با خلوص درصد بود كه از كميانى ايندوفيل هندى Indofil chemical) خريدارى كرديد. ميزان دوز له company, India) ميلى در روغن زيتون يك روز در ميان گاواز شد [. [1]. هشت گروه مورد آزمايش كه در هر گروه 1 موش قرار داشتند، وارد مطالعه شدند. با توجه به دوره اسيرماتوزنز در موش كه هَ روز مىباشد، موشها به مدت ها روز در معرض حشرهش مانكوزب قرار گرفته و در گروههاى درمانى عصاره برى زيتون با دوزهاى مشخص همزمان تجويز كرديد. تجويز در همه گروهها به صورت گاواز، در حجم نهايى ا ميلىليتر بر كيلوگرم و به صورت يك روز در ميان به مدت ه هفته بود. گروه كنترل به منظور شرايط يكسان با ساير گروهها و حذف اثر استرس، به ميزان ا ميلىليتر بر كيلوگرم نرمال سالين دريافت كردند. گروه دريافتى مانكوزب با دوز • له ميلى BW (1/10 بر كيلوگرم وزن بدن محلول در روغن زيتون

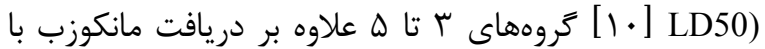
ميزان دوز •إ ميلى گرم بر كيلوگرم وزن بدن محلول در

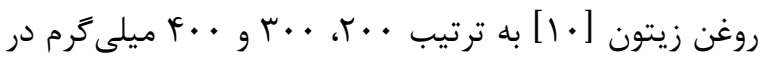
كيلوَّرم عصاره برى زيتون را دريافت نمودند. گروههاى 9 تا

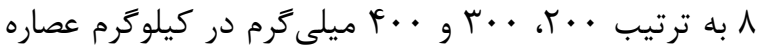
برى زيتون را دريافت نمودند [؟1-11]]. برى گياه زيتون 
• ا ا ثرات حفاظنى عصاره هيدروالكلى برى زيتون بر يارامترهاى اسيرم و كيفيت كروماتين ...

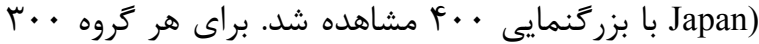

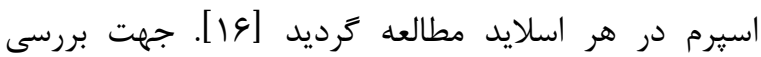

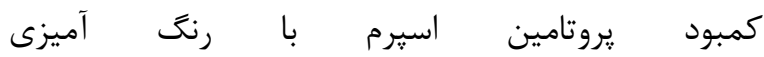
كرومومايسين (Chromomycin A3; CMA3) ابتدا مايع استخراجى از انتهاى وازدفران، يس از ب بار شستشو با PBS ( • ( دور به مدت له دقيقه) از اسيرمها جدا شدند، سيس از اسيرمهاى شسته شده جهت رنگ آميزى CMA3 استفاده شد. به اسيرمهاى شسته شده، حجم مساوى از محلول فيكساتيو كارنوى (متانول و اسيداستيك به نسبت ץ به ()) اضافه شده و به مدت ه دقيقه در حرارت أ درجه سانتى قرار ترفت. پٍ از تهيه اسمير از نمونه، هر اسلايد با ..1 ميكروليتر محلول ها درصد از كرومومايسين در بافر مك الوين با pH=V به مدت · · دقيقه در محيط تاريك رنغ شده سيس اسلايدها با PBS شسته و با لامل مونت گرديد. با استفاده از ميكروسكوٍ فلورسانس - Japan-Nikon) Eclipse600) اسلايد شمارش شد. اسيرمهاى درخشان، CMA3 مثبت و اسيرمهاى فاقد درخشندگى، CMA3 منفى در نظر گَرفته شد [V] إزيابى تخريب DNA به روش SCD ) chromatin dispersion مقدار •r Fernandez شده به روش گراديان خالص اسيرم (غلظت ه تا • ا ميليون در هر ميلىليتر) با •Vميكرو ليتر از آكاروز با درجه ذوب "ايين (low Melting Agarus) دردماى V د درجه سانتى مخلوط شد. سيس نمونه مخلوط شده برروى لامى كه از قبل با آكاروز ه \&|• درصد يوشيده شده، قرار گرفت. با
شده و در يترى ديشى كه حاوى 1/ سىسى نرمال سالين بود قرار داده شد و شاخصهاى ذيل مورد بررسى قرار گرفت: بررسى تراكم اسيرم: با استفاده از لام نئوبار و بر اساس رِ تعداد برحسب ميليون در ميلىليتر ززارش شد. سوسيانسيون محيط حاوى اسيرم، به نسبت 9: ا با فيكساتيو فرمالين •ادرصد رقيق شده و بعد از r دقيقه و فيكس كردن اسِرمها، • 1 ميلىليتر از سوسِانسيون حاوى اسيرم بر روى لام نئوبار قرار داده شده و يك لامل به ابعاد بr ميلىمتر روى آن قرار گرفت. ضخامت مايعى كه در زير لامل يخش مىشود • r ميكرومتر در نظر گرفته شده و لام با

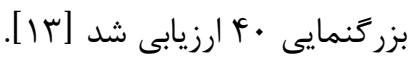
بررسى تحرك اسيرم: حركات اسيرم بر اساس معيار سازمان بهداشت جهانى به أ نوع تقسيم شد: A اسيرمهايى با حركت سريع و جلو رونده، B: اسيرم هايى با حركت آهسته و جلو رونده، C: اسيرمهايى با حركت غير يِيش رونده يا درجا و D: اسيرم هاى بى حركت تقسيم

شد [f]

بررسى شكل اسيرم: يك قطره از سوسيانسيون حاوى اسيرم روى لام كشيده شده و پس از خشك شدن توسط رنخ آميزى ائززين Y و جسباندن لامل روى نمونه، ارزيابى اسبرمها زير ميكروسكوٍ نورى (Nikon TS-100, Japan) با

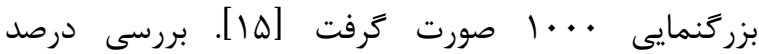
اسيرمهاى غيرطبيعى: جهت بررسى تغييرات شكلى اسيرم از معيار استاندارد Turk et al (2007) استفاده شد. در اين روش اسيرمها با رنگ آميزى ائوزين-نيخروزين مطالعه شد. (Nikon TS-100, سجس اسلايدها زير ميكروسكوٍ نورى 
كَراد ذخيره شد، سيس سطح تستوسترون با استفاده از كيت (ETE126)IBL اندازهيرى شد [11]]. دادهاى جمعآورى شده با استفاده از نرمافزار SPSS نسخه الب مورد تحليل قرار كرفت. نتايج به صورت "انحراف معيار د ميانگين" كزارش شد. به منظور بررسى نرمال بودن توزيع دادهها، از آزمون نايارامترى Kolmogorov-Smirnov استفاده شد و فرض نرمال بودن برقرار بود (ه •>P>). همگنى واريانسها توسط آزمون Levene بررسى شد و فرض همَنى واريانس كروهها نيز يذيرفته شد (ه> (P>). ميانكين كروهها با استفاده از آناليز واريانس يكطرفه و به دنبال آن آزمون تعقيبى Tukey مورد مقايسه قرار گرفت. سطح معنىدارى در آزمونها هـ • •

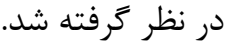

\section{نتايج}

پارامترهاى اسِرم شامل درصد اسيرمهاى زنده، انواع حركات، ناهنجارىهاى ظاهرى، كمبود يروتامين اسيرم، ميزان تفرق كروماتين و ميزان هورمون تستوسترون بررسى كرديد. بر طبق جدول ا، بيشترين تعداد اسيرمهاى زنده در كروه دريافت كننده · · r ميلى گرمى عصاره برى زيتون ديده شد و كمترين ميزان آن در كروه دريافتكننده مانكوزب

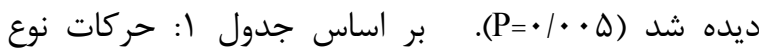
سريع (A)، كند (B) و بى حركت (D) در كروههاى مورد مطالعه اختلاف آمارى معنىدار داشت (ه •/P P). كمترين درصد حركات نوع سريع و كند در كروه دريافتكننده مانكوزب ديده شد. بيشترين حركت نوع D و غير بيشرونده (C) در كروه مانكوزب ديده شد. از طرفى، حركت نوع Cه (C)
كذاشتن يك لامل روى آن، به مدت F دقيقه در دماى F درجه سانتى گراد گذاشته شد. سيس با دقت لامل از سطح لام جدا شده و هر لام به صورت افقى در محلول اسيد كلريدريك ^^•|• نرمال به مدت \ دقيقه در دماى اتاق و در تاريكى قرار داده شد و در درجه حرارت اتاق، به مدت دقيقه در محلول تجزيه كننده اول (pH=V/Q) با محتوى: (تريز اسيدى \&/• مولار، دومركايتواتانول ^|• مولار، اس دى اس (SDS) يك درصد، اتيلن دى اميد تترا استيك اسيد ( ه ميلى مولار) و به دنبال آن در محلول تجزيه (EDTA) كننده دوم (pH=V/Q) با محتوى: (تريز سديم ץ مولار و اس دى اس (SDS) يك درصد) به مدت ه دقيقه قرار گرفت. لام در بافر تريز بورات (pH=V/Q) با محتوى: (تريز بورات 9.٪• مولار و اتيلن دى اميد تترا استيك اسيد (EDTA) ץ.• (EDA) مولار) به مدت r دقيقه شستشو شده و به ترتيب در الكل •V، •9 و • •l درصد، هركدام به مدت r دقيقه آبگيرى شده و بعد از خشك شدن، با محلول رنغ ديفكوئيك رنگَآميزى شده و توسط ميكروسكوٍ نورى (Olympus BH-2, Japan) بررسى شد. DNA با استفاده از اين روش مىتوان ميزان فراگمانتاسيون را با توجه به وجود هاله اطراف هسته و اندازه آن بررسى نمود. در اسيرمهاى با فراگمانتاسيون DNA (هسته اسبرم با هاله كوجى و بدون هاله به عنوان اسيرم تخريب شده) و هسته اسيرم بدون فراگمانتاسيون DNA (هسته اسيرم با هاله بزرى و هاله متوسط) تعيين شد [11]]. جهت بررسى سطح تستوسترون حدود r سىسى خون از قلب حيوان تهيه شده و پلاسماى آن براى آناليز در دماى • r- درجه سانتى - 


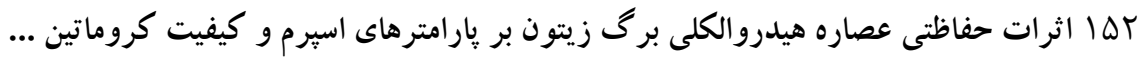

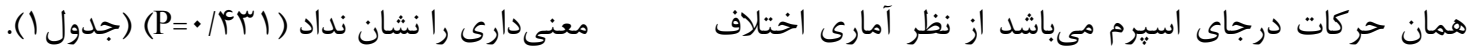

جلدول ا - اثر مانكوزب و دوزهاى مختلف عصاره بركى زيتون بردرصد اسيرمهاى زنله و انواع حركات اسيرم در موش سورى يس از ه هغته درمان

\begin{tabular}{|c|c|c|c|c|c|}
\hline مر بى حركت (درصد) & حركت درجا (درصد) & 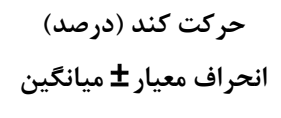 & حركت سريع (درصد) & اسحرمهاى زنده (درصد) & \\
\hline $11 / \Delta \cdot \pm \Delta / \cdot 1$ & $1 \Delta / r \Delta \pm 9 / 99$ & $r \cdot / / r \pm V / V q$ & $\Delta r / l r \pm 11 / 9 r$ & $F \mid / V \Delta \pm 11 / \Delta r$ & كنترل (تعداد=^) \\
\hline$r F / \Lambda \Lambda \pm \xi / g \varphi^{\mathrm{ca}}$ & $r T / r \Delta \pm N / F)$ & $11 / \Delta \cdot \pm r / 1 \varepsilon^{a}$ & $\boldsymbol{F}^{\prime} / \widetilde{\mu} \pm \Lambda / r r^{\mathrm{a}}$ & $r \cdot 10 \cdot \pm 1 \cdot 199^{a}$ & 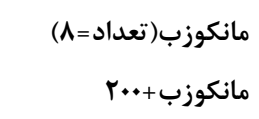 \\
\hline$q / \Lambda \Lambda \pm 1 / T \mu^{b b}$ & $\| r / \Lambda \Lambda \pm \varepsilon / \varepsilon . e$ & $r \varepsilon|\cdot| \pm \varepsilon|q|^{b}$ & $\Delta r / r \Delta \pm \varepsilon / r$. & $F F / \mid r \pm r / g)^{b}$ & 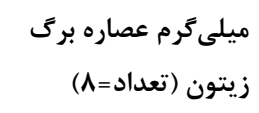 \\
\hline$V / q \cdot \pm r / \wedge \gamma^{b}$ & $\mid r / q \cdot \pm q / v q$ & $r \Delta / / V \pm \Delta / \Lambda T^{b}$ & $\Delta / / \cdot 1 \pm N / \Delta \Lambda$ & $F r / \Lambda \cdot \pm \Delta / \wedge)^{b}$ & 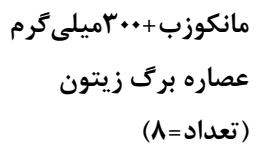 \\
\hline$\Lambda / \Delta \cdot \pm r / \cdot r^{b}$ & $|r / V \Delta \pm \varepsilon / V|$ & $r F / \Lambda \Lambda \pm q / 9 \Delta^{b}$ & $\Delta \Gamma / \Lambda \Lambda \pm \Lambda / r V$ & $r / / \Delta \cdot \pm V / 1 q^{b}$ & 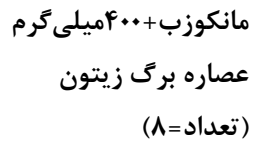 \\
\hline$N / \Delta \cdot \pm r / N r^{b}$ & $\| F / \mid r \pm 1 \cdot / r \Lambda$ & $r \cdot / 0 \cdot \pm r / r$. & $\Delta \varepsilon / \Lambda \Lambda \pm q / r \Delta^{b}$ & 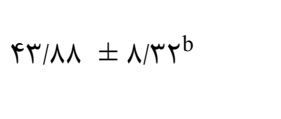 & 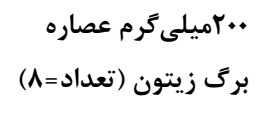 \\
\hline$\Lambda / V \cdot \pm V / / T^{b}$ & $19 / 11 \pm N / \Lambda \Delta$ & $r r / I F \pm \Delta / V \Lambda$ & $\Delta r / \Lambda \cdot \pm V / \mathbb{R}$ & $r \boldsymbol{r} / \cdot r \pm \Lambda / \varepsilon \Lambda^{\mathrm{a}}$ & برَى زيتون (تعداد=ـرم عصاره \\
\hline $\mid \varsigma / \% \wedge \pm q / \wedge \Delta^{b}$ & $1 N / r \Delta \pm 1 \cdot / \& q^{c}$ & $\mid \Lambda / g r \pm V / F \Lambda^{\mathrm{d}}$ & $F G / V \Delta \pm 1 r / 99^{c}$ & $r r / \Delta \cdot \pm N / I r^{a}$ & 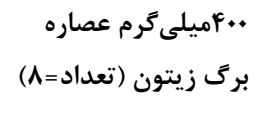 \\
\hline$<\cdot 1 \cdot \cdot 1$ & . Mrtr & $<\cdot 1 \cdot \cdot 1$ & $\cdot / \cdot r V$ & $\cdot / \cdot \Delta$ & مقدار p p \\
\hline
\end{tabular}

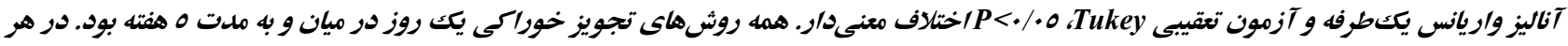

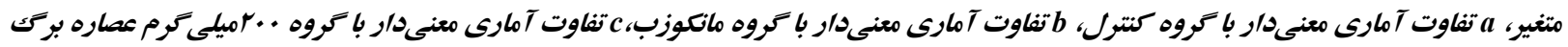

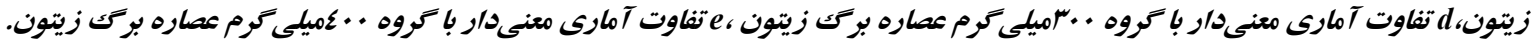

بيشترين كمبود يروتامين اسيرم، در گروه مانكوزب و كم شد. اختلالات ساختارى اسيرم (در ناحيه سر، گردن و دم)

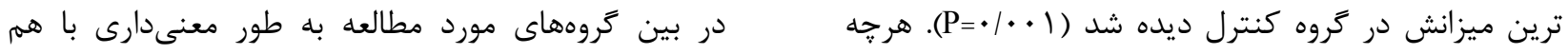

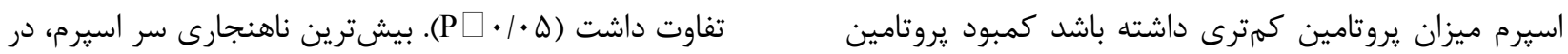

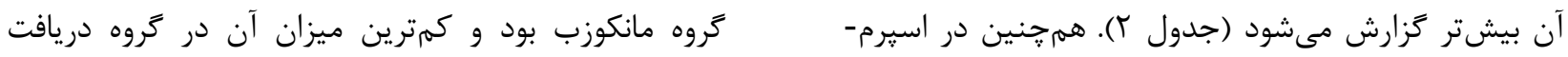

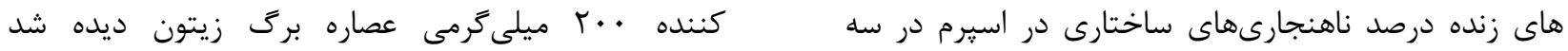

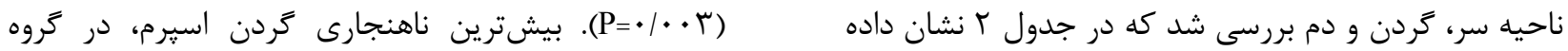




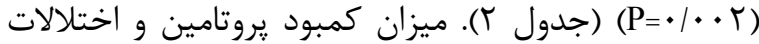

ظاهرى در ناحيه سر، گردن و دم اسيرم در جدول r نشان

داده شده است.

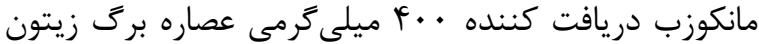
ديده شد و كمترين ميزان آن در كروه كنترل ديده شد

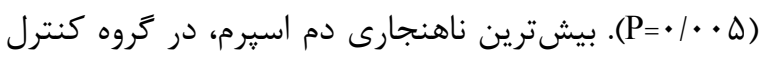
ديده شد و كمترين ميزان آن در خروه مانكوزب ديده شد

جدول بـ - اثز مانكوزب و دوزهاى مختلف عصاره هيدروالكى بركى زيتون بر كمبود بروتامين و درصد اختلالات ساختارى اسيرم در موش سورى بس از 0 هفته دومان

\begin{tabular}{|c|c|c|c|c|}
\hline كمبود يروتامين(درصد) & انحراف معيار د دميانگين اسيرم(درصد) & 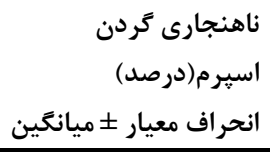 & ناهنجارى سر اسيرم(درصد) & متغير \\
\hline$r \varepsilon / 0 \cdot \pm 1 \cdot / V \Lambda$ & $r \varepsilon / r \Delta \pm \Lambda / \varepsilon \Lambda$ & $\& \Delta / V \Delta \pm \Delta / \& q$ & $\mid \Lambda / \cdot 1 \pm 9 / 11$ & كنترل(تعداد=1) \\
\hline${ }^{\mathrm{a}} \omega \cdot / \Lambda \Lambda \pm \mid \mathcal{F} / \mathcal{} q$ & 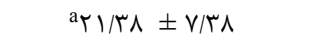 & $\Delta F / I T \pm V / T r$ & $a r / \Delta \cdot \pm \Delta / q$. & مانكوزب(تعداد=^) \\
\hline $\mathrm{b}_{\mathrm{b}} \mathrm{q} / \Lambda \Lambda \pm V / V \mathrm{~T}$ & $\mathrm{~d}_{\mu} \cdot 10 \cdot \pm 9 / 94$ & $\Delta F / / r \pm 1 \cdot / \Lambda \Lambda$ & $\mathrm{b}{ }_{\mathrm{Q} / / \mathrm{\sim} \Lambda} \pm \Delta / \wedge \vee$ & 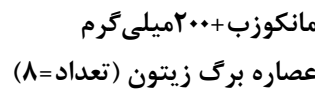 \\
\hline$b_{Y N / \cdot V \pm q / F r}$ & $r V / V \cdot \pm V / I V$ & $\Delta \Delta / r \cdot \pm \varepsilon / f r$ & $\left.{ }^{e}\right) V / l \cdot \pm r / / V$ & 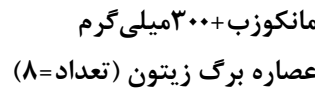 \\
\hline$b_{\curlyvee} / / \Lambda \Lambda \pm q / \vee r$ & ${ }^{a} r \Delta / 11 \pm r / 9 \Lambda$ & ${ }^{a} \Delta V / \notin q \pm \varepsilon / r$. & $I V / \omega \cdot \pm r / V \Lambda$ & 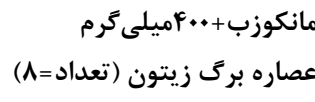 \\
\hline $\mathrm{b}_{\text {Y } N / G T \pm 1 \cdot / r q}$ & $r q / \Lambda \Lambda \pm V / F r$ & $\Delta \Delta / \Gamma \Delta \pm \varepsilon / 9 \Lambda$ & $a_{1} / \mathcal{H} / \Lambda \pm F / \cdot 1$ & 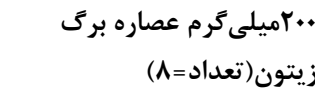 \\
\hline$b_{\Upsilon q / / F} \pm \Lambda / r \Lambda$ & $r \Lambda / \Lambda \cdot \pm \varepsilon / \Lambda V$ & $\Delta \varepsilon / 1 \cdot \pm \Lambda / V{ }^{\epsilon}$ & $b_{1 \Delta / 1} \cdot \pm \Delta / \& r$ & 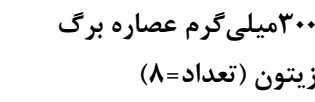 \\
\hline$r \varepsilon / \Lambda \Lambda \pm \mid \varepsilon / \varepsilon r$ & $r q / \Delta \cdot \pm V / \Delta F$ & $\mathcal{F} / \Lambda \Lambda \pm 9 / 9 q^{c}$ & arr/gr $\pm r / 9 \Lambda$ & 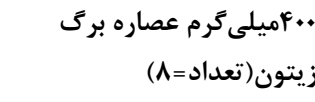 \\
\hline$\cdot 1 \cdot \cdot 1$ & $\cdot / \cdot r$ & $\cdot / \cdot \Delta$ & $\cdot / \cdot r$ & مقدار p \\
\hline
\end{tabular}

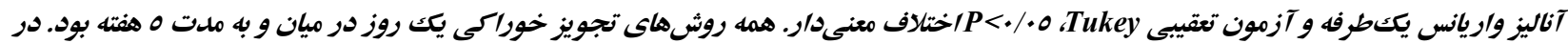

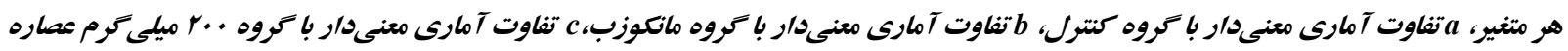

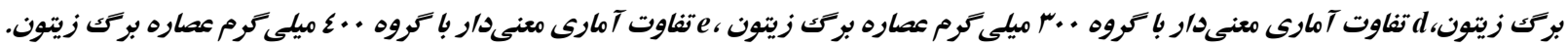
تفرق كروماتين SCD1 و SCD3 و SCD4 در كروههاى مورد جهت بررسى سلامت DNA هسته اسקرم، با اين روش مطالعه اختلاف آمارى معنى دار داشت (ه •/P P). كمترين رنگ آميزى، هاله اطراف سر اسيرم هر خه بزرگتر و ير درصد حركات نوع SCD1 و بيشترين SCD3 در گروه رنتَتر باشد نشاندهنده سلامت DNA هسته اسيرم دريافت كننده مانكوزب ديده شد. در حالىكه بيشترين مىباشد و هر קه اندازه هاله كوجكتر و كم رنگتر باشد درصد حركات نوع SCD1 و كمترين SCD3 در گروه دريافت نشاندهنده تفرق و از هم گسيختتى ساختار هسته است.

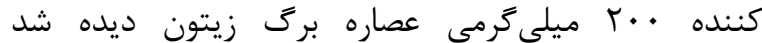
ميانگين تست تفرق كروماتين اسيرم و تستوسترون به تفكيك هر گروه در جدول ץ نشان داده شده است. تست (جدول؟). 
براساس جدول rا، كمترين ميزان تستوسترون درگروه مانكوزب ديده شد و بيشترين ميزان آن در تروه

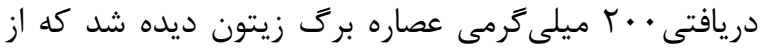

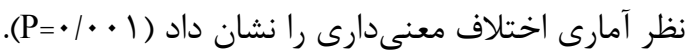

جدول بـ - اثو مانكوزب و دوزهاى مختلف عصاره هيدروالكى بركى زيتون بر درجات تفرق كروماتين اسيرم و ميزان تستوسترون در موش سورى بس

\begin{tabular}{|c|c|c|c|c|c|}
\hline 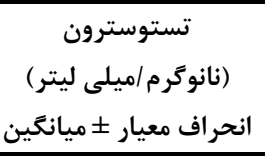 & 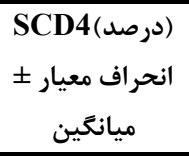 & 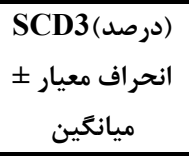 & 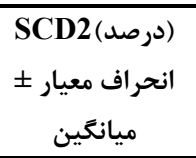 & 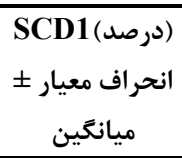 & متغير \\
\hline${ }^{a} \Psi / V \Delta \pm \cdot / r r$ & $1 \cdot / \cdot r \pm r / r q$ & $r / / r \pm N / 9)$ & $r N / / r \pm V / 9 q$ & $a_{\varphi} \cdot / V| \pm V| q \psi$ & كنترل (تعداد=人) \\
\hline $\mathrm{a}_{1 / \Lambda \mathrm{N}} \pm \cdot / \mathrm{rr}$ & ${ }_{\text {arT/GT } \pm V / \& G}$ & $V / V \Delta \pm q / ৭ \varphi$ & $r N / I T \pm 9 / 9 q$ & $r / / \Delta \cdot \pm 9 / r r$ & مانكوزب(تعداد=) \\
\hline$b_{T / F} \cdot \pm \cdot / \mathcal{F V}$ & $\mid Q / / T \pm N / F F$ & $\mathrm{e} / 9 / / \Gamma \pm \Lambda / 9 \Delta$ & $r \Delta / G T \pm N / \Delta \varphi$ & $b_{F} \cdot / I r \pm V / A r$ & 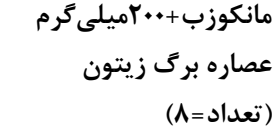 \\
\hline $\mathrm{b}_{\Gamma / \Gamma \Delta \pm} \pm \cdot \pi r$ & $\mid N / \Lambda \cdot \pm r / q$. & $I V / T \cdot \pm 9 / T r$ & $r \Delta / r \cdot \pm V / \Lambda \Delta^{c}$ & $\mathrm{~b}_{\Gamma N / V \cdot \pm \varepsilon / \Gamma r}$ & 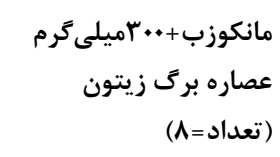 \\
\hline$r / / \& \pm \cdot / V F$ & $\mathrm{~d}_{\tau} \cdot / \Delta \cdot \pm \Delta /{ }^{\prime} \tau$ & $\mathrm{b}_{\mid} r_{/ V \Delta} \pm r /{ }^{\prime} \mid$ & $r G / r \Delta \pm G / r r$ & $b_{\Gamma q / \Delta \cdot \Delta} \pm r / r q$ & 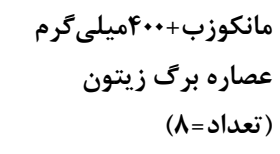 \\
\hline $\mathrm{b}_{\Gamma / q \Delta \pm \cdot / \Gamma \Lambda}$ & $\mathrm{b}_{1} r / g r \pm r / / \Delta$ & $\mathrm{b}_{|r / \Delta|} \pm \Delta / F T$ & $r q / v \Delta \pm q / r \Delta$ & $b_{\kappa} r / l l \pm F / r v$ & 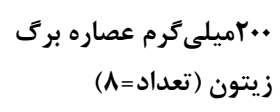 \\
\hline $\mathrm{b}_{T / V F} \pm \cdot\left|\mathcal{F}^{\prime}\right|$ & 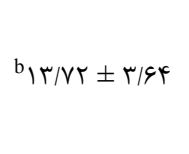 & $\mid \varepsilon / 1 r \pm r / \varepsilon \Delta$ & $r N / \Lambda \Lambda \pm 9 / I r$ & $b_{F} \mid / r \Lambda \pm F / 9 \Delta$ & 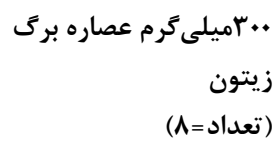 \\
\hline$b_{\Gamma / 4 q} \pm \cdot / \& q$ & ${ }^{a} \Psi \Psi / \widetilde{ } \wedge \pm \Delta / \Delta \Delta$ & $b_{1} \& / V \Delta \pm q / r r$ & $r V / V \Delta \pm r / \Lambda \varphi$ & $r r / r \Lambda \pm V / I V$ & 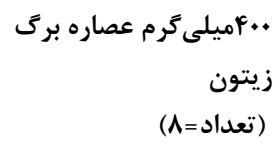 \\
\hline$\cdot 1 \cdot .1$ & $<\cdot|\cdot|$. &.$/ .14$ & .191 & $<\cdot|\cdot \cdot|$ & مقدار p p \\
\hline
\end{tabular}

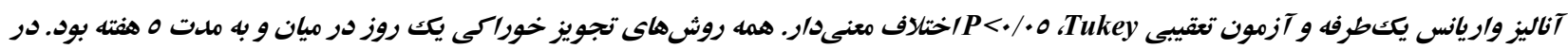

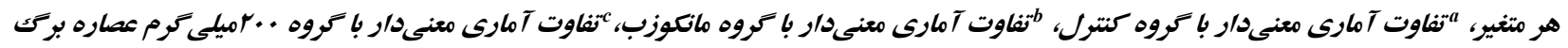

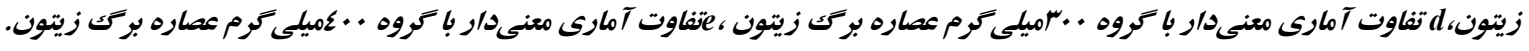

يافت. همرجنين ناهنجارىهاى ساختارى در اسيرم افزايش

بحث

يافت، در حالى كه تجويز عصاره برى زيتون باعث افزايش

بر اساس نتايج مطالعه حاضر، در گروه دريافتى مانكوزب،

قابليت حيات، بهبود شاخصهاى حركتى وكاهش

ميانگين اسيرمهاى زنده وكيفيت حركات اسيرم كاهش

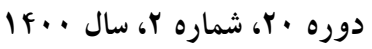

مجله دانشگاه علوم يزشكى رفسنجان 
مثبت آنها بيش از • م درصد باشد، ميزان لقاح CMA3

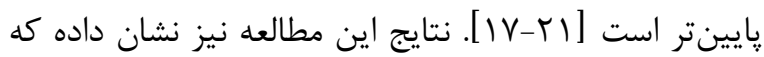
رابطه معنىدارى بين كمبود يروتامين و مورفولوزى اسيرم وجود دارد، به نحوى كه هر جه ميزان كمبود يروتامين بيش تر باشد، ناهنجارىهاى ساختارى در سر و گردن اسيرم بيش تر مىشود [rr]]. گروه مانكوزب داراى كمترين ميزان اسيرمهاى زنده بود. همرجنين اختلالات ساختارى در ناحيه سر اسيرم در گروه مانكوزب بيشتر از ديخر گروهها بود. نتايج اين مطالعه نشان داد كه رابطه يارامترهاى مورفولوزيكى و تحرك اسپرم، با كمبود يروتامين معنىدار است و هرجه كمبود يروتامين كمتر باشد، شاخصههاى بارورى اسيرم بهتر شده و حركات رو به جلو اسيرم بيشتر مىشود كه تأييد كننده مطالعات قبلى است [rr]. همرجنين حضور اسيرم با مورفولوزى غيرطبيعى، بيانكر اين واقعيت است كه اسيرماتوزوا نتوانسته است فرآيند اسِرماتوزنز رأي تكميل كند، لذا عامل تأثير گذار بر فرآيند اسيرميوزنز علاوه بر ميزان تراكم كروماتين، مورفولوزى اسيرم را هم تحت تأثير قرار مىدهد [سץ]. در نتيجه افزايش ناهنجارىهاى ساختارى در اسِرم، احتمالاً با كمبود يروتامين همراه است

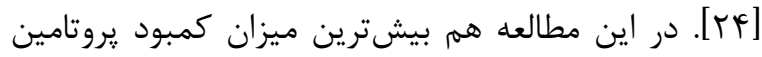
در گروه مانكوزب ديده شد كه بيشترين اختلالات ساختارى و تفرق كروماتين را نيز داشت. از طرفى، بيشترين تعداد اسيرمهاى زنده، بيشترين حركات نوع A و كمترين حركات نوع D در گروه مانكوزب دريافتكننده . ميلى گرم عصاره

$$
\text { برى زيتون ززارش شد. }
$$

ناهنجارىهاى ساختارى در اسيرم شد. تحقيقات نشان دادند كيفيت كروماتين و همرجنين تعداد اسيرم يكى از فاكتورهاى مستقيم اثركذار بر فرآيند بارورى است. اخر بيضهها موفق به توليد اسيرمهاى كافى و سالم نباشند، نابارورى با علت مردانه غير قابل اجتناب خواهد بود [9 19]. از بين دوزهاى . . ك،

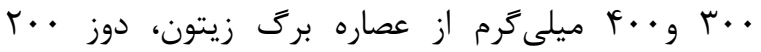
ميلى گرم بر بهبود پارامترهاى اسيرمى مؤثرتر بود. همجنين كمبود يروتامين در اين دوز كمتر ديده شد كه نشاندهنده

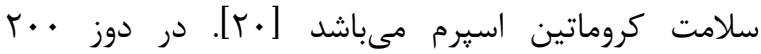
ميلى كمترين ناهنجارى در ناحيه سر اسيرم ديده شد. به طوركلى در طى مراحل اسيرماتوزنز، رشتهاى كروماتين در هسته اسيرم فشرده شده و به جاى هيستونها در ساختار نوكلئوزومى سلولهاى سوماتيك، يروتامينها كه غنى از آرزنين هستند جايگزين مىشوند. در مجموع هـ درصد از هيستونها به وسيله يروتامينها جايكزين مىشوند. تصور مىشود كه اين تراكم و به هم فشردگى هسته اسيرم براى محافظت زنوم اسيرم از استرسهاى خارجى نظير اكسيداسيون يا درجه حرارت بالا مهم باشد [•r]. از ميان كروههاى مورد مطالعه، سلامت كروماتين هسته اسيرم، در كروههاى دريافتكننده عصاره برى زيتون بيشتر بود و از ميان دوزهاى مختلف عصاره برك زيتون، در دوز . ميلى ديده شد. همرجنين بيشترين ميزان تستوسترون در SCD3 دوز · · ميلى Fرم عصاره برگ زيتون ديده شد. مطالعات ديخر محققين، نشان دادند كه در نمونهايى كه درصد 
تغييراتى را در DNA ايجاد نمايد كه تأييدى بر مطالعات ييشين است [YK]. در نهايت يكى از علل مههم نابارورى در مردان، وجود راديكالهاى آزاد در مايع سمينال مىباشد كه باعث اكسيداسيون DNA اسيرم و تغيير بازهاى آلى در ساختمان هسته مى گردد و همجنين موجب كاهش قدرت حركتى و بارورى يا تخريب اسيرم مىشود [ar]. لذا در اين مطالعه به امتحان اين فرضيه يرداختيم كه آيا استفاده از عصاره برگ زيتون به عنوان يك درمان حمايتى، قادر به كاهش آسيب احتمالى مانكوزب بر روى پارامترهاى اسيرم و شاخصهاى بارورى موش سورى مىباشد يا خير؟ و همجنين در جه دوزى مىتواند بيشترين اثر بخشى را داشته باشد؟ درمانهاى زيادى مبنى بر استفاده از اين كياهان انجام شده است، در مطالعهاى Lee و همكارانش نشان دادند كه برى زيتون در مقابله عليه نيتراتها با دارا بودن تركيبات فنولى فراوان و خاصيت آنتىاكسيدانى و ضد ميكروبى، براى سلامت انسانها مفيد و وجود آنها در داروهاى يزشكى مىتواند بسيار مؤثر باشد. در حقيقت تركيبات فنولى باعث شكستن زنجيرههاى راديكالهاى آزاد مىشوند [N]. نشان داده شده كه كَياه زيتون به دليل داشتن تركيبات فنولى مىتواند با مهار فعاليت اكسيدها، التهاب را سركوب كرده و در سلامت سيستم توليد مثلى مؤثر واقع شود [1 ا - II]]. در اين مطالعه ميزان فنول تام بر اساس كاليك اسيد و فلاونوئيد بر اساس روتين تعيين مقدار شد. مطالعات متنوعى به بررسى تركيبات موجود در عصاره برگ زيتون و اثراتش بر سيستم توليدمثل يرداخته اند؛ از جمله، Alirezaei و همكاران با بررسى اولئورويين مشتق از برگ زيتون و بررسى
در اين تحقيق بين كمبود يروتامين و حركات نرمال اسيرم نيز رابطه معنىدار از نوع معكوس وجود داشت كه با مطالعه Fallah و همكاران همخوانى داشت [F] و عنوان نمودند با افزايش ميزان كمبود يروتامين در اسيرم، حركات طبيعى و پِيشرونده اسيرم كاهش مىيابد و بدين نحو بارورى فرد را تحت تأثير قرار مى دهد. Ray و همكارانش عنوان كردند كه اختلالات فلازل (ناحيه دم اسيرم) پِيش آكمى خوبى دارند ولى اختلالات ناحيه آكروزوم اسيرم و ناحيه گردن اسيرماتوزئيد، به شدت موفقيت بارورى رال كاهش مى دهد، لذا به وضوح نقش اختصاصى قسمتهاى

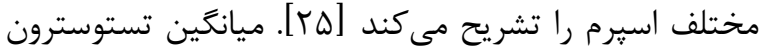
در گروه مانكوزب داراى كمترين ميزان بود. اختلالات در ميزان هورمون تستوسترون و آسيب DNA اسيرم يا ساختار كروماتين آن مىتواند در هر مرحله از اسِرماتوزنز رخ دهد كه در نهايت مىتواند بر قابليت بارورى اسيرم اثركذار باشد [عץ]. آسيب DNA در اسيرماتوزواى بالغ مىتواند به علت نقايصى در بستهبندى كروماتين باشد كه ممكن است از شكستكىهاى آندرورنى در DNA، روند آيويتوز قبل از انزال اسيرمها و يا توليد بالاى راديكالهاى آزاد اكسيرن باشد كه باعث صدمه به DNA اسيرم شده باشد [rV]. از آنجايى كه آسيب يا شكست در DNA اسيرم وابسته به مقدار يروتامين هسته مىباشد، هرجه اسيرم، ميزان پروتامين بيشترى داشته باشد در مقابل شكست DNA مقاومتر مىباشد [•r]. در اين يزوهش مصرف مانكوزب ميزان كمبود يروتامين اسيرم را افزايش داد، لذا مىتوان نتيجه كَرفت كه مانكوزب به عنوان توليد كننده راديكال آزاد اكسيثن مىتواند 
اندازهيرى آنزيمهاى آنتىاكسيدانى موجود در عصاره برگ

زيتون و تعيين اثرات حفاظتى آن بر سميتهاى كبدى و كليوى ناشى از مانكوزب و يا ساير آلكيلهكنندهها جهت مطالعات آتى ييشنهاد مىشود.

\section{نتيجه كيرى}

براساس نتايج مطالعه حاضر، تيمار با دوز . . ميلى گرم بر كيلوگرم عصاره بركزيتون، اثرات مثبتى بر روند اسيرماتوزنز، يروتامين و سلامت كروماتين هسته اسيرم موشهاى در معرض مانكوزب داشت، در حالى كه دوز ·. و . F ميلى Fرم اين عصاره جندان بهبود مناسبى را در شاخصههاى اختصاصى اسيرمها ايجاد نكرد. لذا به نظر

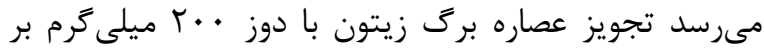
كيلوَرم احتمالاً بتواند جهت حفاظت و بهبود وضعيت اسيرماتوزنز افرادى كه به ناجار در معرض مانكوزب يا ساير آلكيله كنندها قرار مى گيرند مؤثرتر باشد.

\section{تشكر و قدردانى}

اين مطالعه حاصل پاياننامه دانشجوى مقطع كارشناسى ارشد رشته بيوشيمى دانشًاه آزاد اسلامى واحد شيراز بوده، لذا از معاونت محترم يزوهشى جهت حمايت مالى پاياننامه و اساتيد محترم گروه جهت ثبت پايانامه كمال تشكر و قدردانى به عمل مى آيد.
آنزيمهاى آنتىاكسيدانى َلوتاتيون (Glutathione) و سويراكسيددسموتاز (Superoxide dismutase) مشاهده كردند كه اثرات منفى اكسيدهاى ايجاد شده توسط الكل بر سيستم توليدمثلى موشصحرايى نر، با اولئورويين كاهش مىيابد [•r]. همرجنين Moienie و همكاران نيز با مشاهده كاهش سطح هورمونهاى جنسى و سلولهاى اسيرماتوگونى در موشهاى ديابتى، بي بردند كه اثرات جانبى ديابت با استفاده از برك زيتون در دوز · •ه ميلى گرم بر كيلوگرم

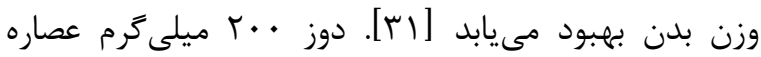
برگ زيتون، در اين مطالعه بهترين حفاظت اسيرمى را ايجاد

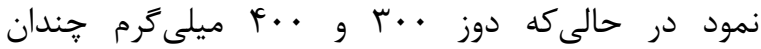
پارامترهاى اسيرم را بهبود نبخشيد. در مطالعه Hakemi و

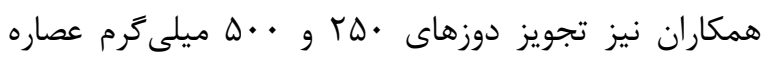
برگزيتون بر اثرات تجويز بوسولفان مؤثر بود، در حالى كه

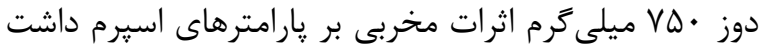
[11]. همسو با نتايج اين مطالعه، تحقيقات Heilman و همكاران نشان داد كه عصارههاى گياهان ممكن است در دوز هاى بالاتر اثر تخريبى داشته باشند از جمله برگ زيتون كه آن نيز در غلظتهاى بالا تأثير مخرب دارد [بس]. از محدوديتهاى اين مطالعه اينكه مكانيسمهاى مولكولى درگير در روند حفاظتى عصاره برگزيتون بررسى نشد لذا نياز به مطالعات بيشترى دارد. همرجنين ارزيابى و ور 


\section{References}

[1] Alahmar AT. Role of oxidative stress in male infertility: An updated review. J Hum Reprod Sci 2019; 12(1): 4-18.

[2] Agarwal A, Mulgund A, Hamada A, Chyatte MR. A unique view on male infertility around the globe. Reprod Biol Endocrinol 2015; 13(1): 1-9.

[3] Rajender S, Avery K, Agarwal A. Epigenetics, spermatogenesis and male infertility. Mutat Res Rev Mutat Res 2011; 727(3): 62-71.

[4] Mathur N, Pandey G, Jain GC. Pesticides: A review of the male reproductive toxicity. $J$ Herbal Med Toxicol 2010; 4(1): 1-8.

[5] Kwon D, Chung HK, Shin WS, Park YS, Kwon SC, Song JS, et al. Toxicological evaluation of dithiocarbamate fungicide mancozeb on the endocrine functions in male rats. Mol Cell Toxicol 2018; 14(1): 105-12.

[6] Neto FT, Bach PV, Najari BB, Li PS, Goldstein M. Spermatogenesis in humans and its affecting factors. Semin Cell Dev Biol 2016; 59: 10-26.
[7] Mehrpour O, Karrari P, Zamani N, Tsatsakis AM, Abdollahi M. Occupational exposure to pesticides and consequences on male semen and fertility: a review. Toxicol Lett 2014; 230(2): $146-56$

[8] Lee OH, Lee BY. Antioxidant and antimicrobial activities of individual and combined phenolics in Olea europaea leaf extract. Bioresour Technol 2010; 101(10): 3751-4

[9] Sangi SM, Bawadekji A, Alotaibi NM, Aljalaud NA. Preventive and Curative Effects of Metformin, Nigella sativa, Punica granatum and Zingiber officinale on Male Reproductive Dysfunction in Diabetic Rats. Int J Pharm Res Allied Sci 2019; 8(2): 48-57.

[10] Saddein E, Haghpanah T, Nematollahi-Mahani SN, Seyedi F, Ezzatabadipour M. Preventative effects of vitamin $\mathrm{E}$ on testicular damage and sperm parameters in the first-generation mice pups due to pre-and postnatal mancozeb exposure. J Toxicol 2019; 1: 1-12. 
[11] Hakemi SG, Sharififar F, Haghpanah T, Babaee A, Eftekhar-Vaghefi SH. The effects of olive leaf extract on the testis, sperm quality and testicular germ cell apoptosis in male rats exposed to busulfan. Int J Fertil Steril 2019; 13(1): 57-65.

[12] Yaghoubi A, Shahedi A, Akbari H, NematollahiMahani SN. Do insulin replacement and omega3 protect the male reproductive function of the streptozotocin-induced diabetic mice?. J Nutr Metab 2017; 2: 6-12.

[13] Bakos HW, Mitchell M, Setchell BP, Lane M. The effect of paternal diet-induced obesity on sperm function and fertilization in a mouse model. Int J Androl 2011; 34(5): 402-10.

[14] Maggavi RR, Pujari SA, Vijaykumar CN. Motility Analysis with Morphology: Study Related to Human Sperm. Procedia Comput Sci 2019; 152: 179-85.

[15] Mangiagalli MG, Cesari V, Cerolini S, Luzi F, Toschi I. Effect of lycopene supplementation on semen quality and reproductive performance in rabbit. Qom Univ Med Sci J 2012; 20(3): 141-8. [Farsi]

[16] Ni K, Spiess AN, Schuppe HC, Steger K. The impact of sperm protamine deficiency and sperm DNA damage on human male fertility: a systematic review and meta-analysis. Andrology 2016; 4(5): 789-99.

[17] Fernandez JL, Muriel L, Rivero MT, Goyanes V, Vazquez R, Alvarez JG. The sperm chromatin dispersion test: a simple method for the determination of sperm DNA fragmentation. $J$ Androl 2003; 24(1): 59-66.

[18] Ammar O, Houas Z, Mehdi M. The association between iron, calcium and oxidative stress in seminal plasma and sperm quality. Environ Sci Pollut Res Int 2019; 26(14): 14097-105.

[19] Akbari H, Saleh M, Heidari MH, Ghaffari Novin M, Azargashb E. Evaluation of sperm parameters and chromatin abnormalities in male infertility using CASA and chromatin dispersion test. Research in Medicine 2013; 36(4): 176-83.

[Farsi] 
[20] Nasr-Esfahani MH, Naghshizadian N, Imani H, Razavi S, Mardani M, Kazemi S, et al. Can sperm protamine deficiency induce sperm premature chromosomal condensation?. Andrologia 2006; 38(3): 92-8.

[21] Akbari H, Forouzandeh H, Ghavamizadeh M. Protective Effects of Zinc Supplement on Chromatin Deficiency and Sperm Parameters in Streptozotocin-Induced Diabetic Rats. Intern Med J 2020; 27(5): 1-5.

[22] Salehi M, Akbari H, Heidari MH, Molouki A, Murulitharan K, Moeini H, et al. Correlation between human clusterin in seminal plasma with sperm protamine deficiency and DNA fragmentation. Mol Reprod Dev 2013; 80(9): $718-24$.

[23] Zini A, Albert O, Robaire B. Assessing sperm chromatin and DNA damage: clinical importance and development of standards. Andrology 2014; 2(3): 322-5.

[24] Fallah A, Mohammad-Hasani A, Colagar AH. Zinc is an essential element for male fertility: a review of $\mathrm{Zn}$ roles in men's health, germination, sperm quality, and fertilization. $J$ Reprod Infertil 2018; 19(2): 69-81.

[25] Ray PF, Toure A, Metzler-Guillemain C, Mitchell MJ, Arnoult C, Coutton C. Genetic abnormalities leading to qualitative defects of sperm morphology or function. Clin Genet 2017; 91(2): 217-32.

[26] Rathke C, Baarends WM, Awe S, RenkawitzPohl R. Chromatin dynamics during spermiogenesis. Biochim Biophys Acta 2014; 1839(3): 155-68

[27] Ménézo Y, Dale B, Cohen M. DNA damage and repair in human oocytes and embryos: a review. Zygote 2010; 18(4): 357-65.

[28] Cardoso JP, Cocuzza M, Elterman D. Optimizing male fertility: oxidative stress and the use of antioxidants. World J Urol 2019; 37(6): 1029-34

[29] Almeer RS, Abdel Moneim AE. Evaluation of the protective effect of olive leaf extract on 
cisplatin-induced testicular damage in rats. Oxid

Med Cell Longev 2018; 7(6): 13-8.

[30] Alirezaei M, Kheradmand A, Heydari R, Tanideh N, Neamati S, Rashidipour M. Oleuropein protects against ethanol-induced oxidative stress and modulates sperm quality in the rat testis. Med J Nutrition Metab2012; 5(3): 205-11.
[31] Moienie F, Mokhtari M, Sharifi E. The effect of hydro-alcoholic leaf extract of olea europaea on the levels of gonadotropins, sex hormones and spermatogenesis in diabetic rat. J Anim Physiol Dev 2014; 5: 11-6.

[32] Heilman J, Anyangwe N, Tran N, Edwards J, Beilstein P, López J. Toxicological evaluation of an olive extract, H35: subchronic toxicity in the rat. Food Chem Toxicol 2015; 84: 18-28.. 
ك ا ا اثرات حفاظتى عصاره هيدروالكلى برى زيتون بر يارامترهاى اسيرم و كيفيت كروماتين ...

\title{
Protective Effects of Olive Leaf Hydroalcoholic Extract on Sperm Parameters and Chromatin Quality in NMRI Mice Exposed to the Insecticide Mancozeb: An Experimental Study
}

\author{
M. Ashkanani ${ }^{1}, \underline{\text { H. } \text { Akbari }^{2}}$ \\ Received:25/11/20 Sent for Revision: 26/112/20 Received Revised Manuscript:04/04/21 Accepted:05/04/21
}

Background and Objectives: Improper use of chemical pesticides such as Mancozeb (MZB) leads to genital injuries. The aim of this study was to determine the effect of different doses of olive leaf extract (OLE) on reproductive damage in male mice exposed to MZB.

Materials and Methods: In this experimental study, 64 adult male NMRI mice (10 to 12 weeks) were randomly divided into 8 groups $(\mathrm{n}=8)$ including control (Normal saline recipient), Mancozeb (MZB) recipient (500 mg/kg), MZB $(500 \mathrm{mg} / \mathrm{kg})+(200,300$ and $400 \mathrm{mg}$ of OLE) and OLE group at doses of (200, 300 and $400 \mathrm{mg})$ and were treated by gavage every other day for 35 days. Then, the mice were killed by cervical dislocation; heart blood samples were drawn to measure serum testosterone level and epididymis removed to examine sperm. Different indicators of sperm analysis (number, motility and morphology), protamine and chromatin health were examined. Data were analyzed using one-way ANOVA and Tukey’s multiple comparisons test.

Results: The lowest protamine levels $(p=0.001)$ and the lowest alive sperms $(p=0.005)$ were seen in the MZB group. There was a significant decrease in head abnormalities $(p=0.003)$ and immobile sperm $(p<0.001)$ in OLE groups. At a dose of $200 \mathrm{mg} / \mathrm{kg}$ OLE, the highest chromatin health $(\mathrm{p}<0.001)$, the highest rapid sperm motility $(\mathrm{p}=0.037)$ and the highest testosterone level $(\mathrm{p}=0.001)$ were observed.

Conclusion: The highest efficacy of OLE was seen at a dose of $200 \mathrm{mg} / \mathrm{kg}$; therefore, consumption of this extract in the same dose can probably be considered as a supportive compound in the diet of high-risk people exposed to MZB.

Key words: Mancozeb, Sperm, Olive leaf extract, Mice, Infertility

Funding: This study was funded by Shiraz Branch of Islamic Azad University.

Conflict of interest: None declared.

Ethical approval: The Ethics Committee of Shiraz Branch of Islamic Azad University approved the study (IR.IAU.SHIRAZ.REC.1399.027).

How to cite this article: Ashkanani M, Akbari H. Protective Effects of Olive Leaf Hydroalcoholic Extract on Sperm Parameters and Chromatin Quality in NMRI Mice Exposed to the Insecticide Mancozeb: An Experimental Study. J Rafsanjan Univ Med Sci 2021; 20 (2): 147-62. [Farsi]

1-MSc Student of Biochemistry, Department of Biochemistry ,Shiraz Branch, Islamic Azad University, Shiraz, Iran ORCID: 0000-0001-8729-1696

2- Assistant professor of anatomical sciences, Cellular and Molecular Research Center, Gerash University of Medical Sciences, Gerash, Iran, ORCID: 0000-0002-9417-1390

(Corresponding Author) Tel: (071) 52448101, Fax: (071) 52452339, E-mail address: anaakbari91@gmail.com

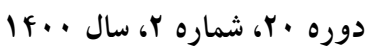

مجله دانشگاه علوم يزشكى رفسنجان 